УДК: 004.75

\title{
Exact calculation of a posteriori probability distribution with distributed computing systems
}

\author{
K. I. Kholodkov ${ }^{\text {a }}$ I. M. Aleshin ${ }^{\text {b }}$ \\ Schmidt Institute of Physics of the Earth RAS, Russia, 123995, Moscow, B. Grouzinskaya str. 10, b. 1 \\ E-mail: ${ }^{a}$ keir@ifz.ru, ${ }^{b}$ ima@ifz.ru
}

Received October 10, 2014

We'd like to present a specific grid infrastructure and web application development and deployment. The purpose of infrastructure and web application is to solve particular geophysical problems that require heavy computational resources. Here we cover technology overview and connector framework internals. The connector framework links problem-specific routines with middleware in a manner that developer of application doesn't have to be aware of any particular grid software. That is, the web application built with this framework acts as an interface between the user 's web browser and Grid's (often very) own middleware.

Our distributed computing system is built around Gridway metascheduler. The metascheduler is connected to TORQUE resource managers of virtual compute nodes that are being run atop of compute cluster utilizing the virtualization technology. Such approach offers several notable features that are unavailable to bare-metal compute clusters.

The first application we've integrated with our framework is seismic anisotropic parameters determination by inversion of SKS and converted phases. We've used probabilistic approach to inverse problem solution based on a posteriory probability distribution function (APDF) formalism. To get the exact solution of the problem we have to compute the values of multidimensional function. Within our implementation we used brute-force APDF calculation on rectangular grid across parameter space.

The result of computation is stored in relational DBMS and then represented in familiar human-readable form. Application provides several instruments to allow analysis of function's shape by computational results: maximum value distribution, 2D cross-sections of APDF, 2D marginals and a few other tools. During the tests we've run the application against both synthetic and observed data.

Keywords: distributed computing, virtual computing cluster, geophysics

Citation: Computer Research and Modeling, 2015, vol. 7, no. 3, pp. 539-542. 


\title{
Точное вычисление апостериорной функции распределения вероятно- сти при помощи вычислительных систем
}

\author{
К. И. Холодков, И. М. Алёшин
}

Институт физики Земли им. О. Ю. Шмидта РАН, Россия, 123995, г. Москва, Б. Грузинская ул., 10, cmp. 1

Представленная работа описывает опыт создания и развёртывания веб-приложения и гридинфраструктуры для решения задач геофизики, требующих большого количества вычислительных ресурсов. В работе представлен обзор технологии и механизма платформы интеграции геофизических приложений с распределёнными вычислительными системами. Разработанная платформа предоставляет собой промежуточное программное обеспечение, предоставляющая удобный доступ к развёрнутым на ее основе геофизическим приложениям. Доступ к приложению осуществляется через веб-браузер. Интеграция новых приложений облегчается за счёт предоставляемого стандартного универсального интерфейса взаимодействия платформы и новым приложением.

Для организации распределённой вычислительной системы применено ПО Gridway, экземпляр которого взаимодействует с виртуализированными вычислительными кластерами. Виртуализация вычислительных кластеров предоставляет новые возможности при утилизации вычислительных ресурсов по сравнению с традиционными схемами организации кластерного ПО.

В качестве пилотной задачи использована обратная задача определение параметров анизотропии коры и верхней мантии по данным телесейсмических наблюдений. Для решения использован вероятностный подход к решению обратных задач, основанный на формализме апостериорной функции распределения (АПФР). При этом вычислительная задача сводится к табулированию многомерной функции. Результат вычислений представлен в удобном для анализа высокоуровневом виде, доступ и управление осуществляется при помощи СУБД. Приложение предоставляет инструменты анализу АПФР: расчет первых моментов, двумерные маргинальные распределения, двумерные сечения АПФР в точках ее максимума. При тестировании веб-приложения были выполнены вычислены как синтетических, так и для реальных данных.

Ключевые слова: распределенные вычислительные системы, виртуальный вычислительный кластер, геофизика 


\section{Introduction}

One of our previous implementation of determination of anisotropic parameters by seismic data inversion problem utilized the EGEE grid infrastructure. The infrastructure used the gLite middleware, despite the use of gLite middleware the computation procedure startup was carried out by hand mostly.

Large scale computational resources are difficult to utilize and maintain and middleware provides a sort of unified interface to it. Obviously researches that lack sufficient large scale computing skills require another level of usability improvement. Often this improvement is archived by building a socalled wrapper above complex middleware interfaces. This is what we've done in [Aleshin, 2013; Kholodkov, 2013]. That research involved the creation of own grid infrastructure with Globus Toolkit across three Academic institutions. Major drawbacks include complexity of application changes and overall system akwardness. The later was caused by security and transfer services bypass. We've written our own implementation for user authentication and job data delivery but we couldn't drop GSI and GridFTP out of Globus infrastructure. This led us to several conceptual improvement - the new wrapper has to be two-level one. The first level - an integration platform that makes all interaction with grid middleware and provides simplified API for application development, which is the second level of a two-layer concept. Additionaly we've switched to Gridway.

\section{The implementation}

New implementation utilizes the same hardware as previous experiment. Particularly, we've made use of virtualization to provide flexible resources to computation project and to allow easy maintenance. The virtualization uses hardware acceleration so compute power isn't wasted.

Switching to Gridway allowed us to build a simplified grid. Gridway metascheduler runs on separate node and talks to TORQUE queue manages directly thanks to DRM4G[DRM4G, 2014] patches to Gridway.

The integration platform connects application with grid middleware. The platform is built using common modern coding techniques for easy modification and extension. Most parts of platform are coded in php with CodeIgniter, which is an Model-View-Controller programming framework. Additionaly the platform utilizes a V8 Javascript Engine (node.js) for utility jobs. Application-specific modules are separated from common shared code allowing the researcher to easy port similar (data independent class) applications to run on this platform. As pilot project we've implemented determination of anisotropic parameters of crust and upper mantle by teleseismic data problem.

\section{Pilot problem}

The pilot provides a simple web-interface for determination of anisotropic parameters of crust and upper mantle by teleseismic data problem. The major difference from our previous approach [Алёшин, 2009] is use of APDF formalism to find best fit. The idea of APDF takes data and model error estimation into accout in the way that the outcome of the solver is best-fit-probability to parameter set relation.

Renewed web interface is now inverse-problem oriented and the only question regarding the grid itself user has to answer is about application split factor - how small should slices of entire application be - and this will be addressed in future.

In addition to monitoring the new interface features automatic result processing by generating a set of parameter-set-to-APDF relation cross-sections also available via web-interface.

\section{Conclusion}

This experiment indicated that grid software needs additional high-level API for scientific applications, which is addressed by software described in this paper that allows users to port their own 
applications to run on grid. Gridway with DRM4G and TORQUE makes a quick and easy solution for experimental grids.

\section{References}

Aleshin I. M., Koryagin V. N., Sukhoroslov O. V., Kholodkov K. I., Shogin A. N. [in Russian] Инверсия сейсмических данных: высокоуровневый веб-интерфейс к инструментарию Globus Toolkit // Scientific and Technical Information Processing. - 2013. — Series 1, No. 7.

Aleshin I. M., Mishin D. Yu., Zhizhin M. N., Koryagin V. N., Medvedev D. P., Novikov A. M., Peregoudov D. V. [in Russian] Применение распределенных вычислительных систем при определении параметров сейсмической анизотропии коры и верхней мантии // Geophysical Research. - 2009. - Vol. 10, No. 4. - P. 34-47.

DRM4G (Distributed Resource Management for Grid) [online] // Santander Meteorology Group, Instituto de Fisica de Cantabia - 2014 - URL: https://meteo.unican.es/trac/wiki/DRM4G (дата обращения: 17.12.2014);

Kholodkov K. I. Implementation of seismic data inversion as grid-backed web service // Russian journal of Earth sciences. — 2013. — № 13. 